\title{
PENINGKATAN AKTIVITAS DAN HASIL BELAJAR SISWA SMP MENGGUNAKAN MODEL PROBLEM BASED LEARNING
}

\author{
Yulia Alisa ${ }^{1^{*}}$, Yennita ${ }^{1}$, Sri Irawati ${ }^{1}$ \\ ${ }^{1}$ Program Studi Pendidikan Biologi, Fakultas Keguruan dan Ilmu Pendidikan, Universitas Bengkulu \\ Email: yuliaalisa72@gmail.com
}

\begin{abstract}
Abstrak
Penelitian ini bertujuan untuk mendeskripsikan aktivitas guru dan siswa dalam pembelajaran, serta hasil belajar siswa dengan penerapan model Problem Based Learning (PBL). Jenis penelitian ini adalah penelitian tindakan kelas dengan metode deskriptif. Penelitian ini di lakukan selama dua siklus, setiap siklus terdiri dari tahap perencanaan, pelaksanaan, pengamatan, dan refleksi. Subyek penelitian ini adalah peneliti yang berperan sebagai guru dan seluruh siswa kelas $\mathrm{VII}_{1} \mathrm{SMPN} 14$ Kota Bengkulu. Instrumen penelitian yang di gunakan adalah lembar observasi yaitu untuk mengetahui aktivitas guru dan siswa, serta lembar tes yang di gunakan untuk mengetahui hasil belajar IPA siswa. Hasil analisis data observasi aktivitas guru siklus I diperoleh skor rata-rata 30,6 (Baik) dan siklus II meningkat menjadi 31,6 (Baik). Untuk hasil analisis data observasi aktivitas siswa juga mengalami peningkatan, dimana pada siklus I diperoleh skor rata-rata 30,6 (Baik), sedangkan pada siklus II meningkat menjadi 31 (Baik). Untuk persentase ketuntasan belajar klasikal yang diperoleh siswa pada siklus I yaitu 70,6\% (Tidak tuntas) meningkat menjadi 88,2\% (Tuntas) disiklus II.
\end{abstract}

Kata kunci : Problem Based Learning (PBL), Aktivitas Guru, Aktivitas Siswa, Hasil Belajar

\begin{abstract}
Abstrack
This study aims to describe the activities of teachers and students in learning, and student learning outcomes with the application of Problem Based Learning design (PBL). This type of research is classroom action research with descriptive method. This research was conducted for two cycles, each cycle consisting of planning, implementation, observation, and reflection. The subject of this research is the researcher who acts as the teacher and all the students of class VII1 SMPN 14 Bengkulu city. The research instrument that is used is observation sheet that is to know the activity of teacher and student, and test sheet that is used to know student learning result of science. The result of observation data of teacher activity activity of cycle I got average score 30,6 (Good) and cycle II increased to 31,6 (Good). For the results of data analysis of student activity observation also increased, where in cycle I obtained average score 30.6 (Good), while in cycle II increased to 31 (Good). For the percentage of classical learning completeness obtained by students in the first cycle that is $70.6 \%$ (Unfinished) increased to $88.2 \%$ (completed) cycle II.
\end{abstract}

Keywords : Problem Based Learning (PBL), Teacher Activity, Student Activity, Learning Outcomes 


\section{PENDAHULUAN}

Dalam Undang-Undang Nomor 20 tahun 2003 tentang Sistem Pendidikan Nasional, Bab I Pasal 1 ayat (1) dikemukakan bahwa pendidikan adalah usaha sadar dan terencana untuk mewujudkan suasana belajar dan proses pembelajaran agar peserta didik secara aktif mengembangkan potensi dirinya untuk memiliki kekuatan spiritual keagamaan, pengendalian diri, kepribadian, kecerdasan, akhlak mulia, serta keterampilan yang diperlukan dirinya, masyarakat, bangsa dan negara (Arifin, 2012).

Berdasarkan data awal peneliti, yaitu dari pengalaman yang di lakukan sebanyak dua kali pertemuan terhadap pembelajaran yang dilakukan oleh guru IPA pada saat peneliti melaksanakan praktik pengalaman lapangan (PPL)/Magang III di kelas $\mathrm{VII}_{1}$ SMPN 14 Kota Bengkulu, diperoleh informasi bahwa guru belum menerapkan model pembelajaran secara bervariasi, sehingga guru hanya menyampaikan materi dengan ceramah saja. Sedangkan dalam penerapan kurikulum 2013, terdapat beberapa model pembelajaran yang dapat diterapkan seperti Project Based Learning, Siklus Belajar 5E, Discoveri Learning, Problem Based Learning, dan model pembelajaran lainnya.

Sedangkan informasi yang di dapatkan dari guru IPA mengenai hasil belajar pada mata pelajaran IPA siswa kelas $\mathrm{VII}_{1}$ ini, ternyata dari rerata nilai hasil belajar IPA rata-rata nilai ulangan harian siswa pada semester 1 (satu) hanya 18 orang yang lulus KKM 75 dari 34 siswa. Dengan mempertimbangkan permasalahan tersebut, maka peneliti bekerjasama dengan guru IPA SMPN 14 Kota Bengkulu, untuk merencanakan proses perbaikan pembelajaran IPABiologi di kelas $\mathrm{VII}_{1}$. Salah satu alternatif yang telah dilakukan adalah dengan membantu siswa dalam meningkatkan hasil belajar IPA-Biologi melalui penelitian tindakan kelas dengan judul "Penerapan Model Problem Based Learning untuk Meningkatkan Aktivitas dan Hasil Belajar IPA Siswa Kelas $\mathrm{VII}_{1}$ SMPN 14 Kota Bengkulu Materi Ekosistem.

\section{METODE PENELITIAN}

Penelitian ini menggunakan metode deskriptif, Menurut Nawawi (2007) dalam Darmadi (2014) metode deskriptif dapat diartikan sebagai prosedur pemecahan masalah yang diselidiki dengan menggambarkan, melukiskan keadaan subyek, obyek penelitian (seseorang, lembaga, masyarakat, dan lain-lain) pada saat sekarang berdasarkan fakta-fakta yang tampak, atau sebagaimana adanya. Penelitian ini mendeskripsikan aktivitas guru, aktivitas siswa, dan hasil belajar IPA kelas VII 1 SMPN 14 Kota Bengkulu.

Pengambilan data penelitian dilakukan pada bulan April - Mei 2017 dengan subyek penelitian adalah peneliti itu sendiri yang berperan sebagai guru Biologi dan seluruh siswa kelas $\mathrm{VII}_{1}$ SMPN 14 Kota Bengkulu tahun ajaran 2016/2017 yang berjumlah 34 orang siswa terdiri dari 14 orang laki-laki dan 20 orang perempuan.

Teknik pengumpulan data dalam penelitian ini adalah observasi dan tes. Observasi dilakukan untuk mengetahui aktivitas guru dan aktivitas siswa selama proses pembelajaran IPA-Biologi dikelas $\mathrm{VII}_{1}$ SMPN 14 Kota Bengkulu. Sedangkan tes digunakan untuk mengumpulkan data hasil belajar siswa secara individu setelah proses belajar dengan menerapkan model Problem Based Learning yang mengacu pada $\begin{array}{lll}\text { kompetensi dasar } & \text { (KD) } 3.8\end{array}$ Mendeskripsikan interaksi antar mahluk 
hidup dan lingkungannya, 4.12 Menyajikan hasil observasi terhadap interaksi mahluk hidup dengan lingkungan sekitarnya.

Dari data hasil observasi terhadap aktivitas guru dan siswa dalam proses pembelajaran IPA ini dianalisis dengan menghitung rata-rata skor pengamat sehingga dapat diungkapkan secara deskriptif. Data hasil observasi terhadap aktivitas guru dan siswa tersebut digunakan untuk merefleksi tindakan yang telah dilakukan. Data hasil belajar IPA siswa dianalisis dengan cara mengolah data hasil post tes sehingga dapat diketahui tingkat keberhasilan atau ketuntasan siswa di kelas $\mathrm{VII}_{1}$ SMPN 14 Kota Bengkulu. Untuk menganalisis ketercapaian hasil belajar siswa maka dihitung persentase kriteria ketuntasan belajar siswa (Trianto, 2012), dengan rumus :

$$
K B=\frac{N S}{N} \times 100 \%
$$

Keterangan:

$\mathrm{KB}=$ Ketuntasan belajar klasikal

NS = jumlah siswa yang mendapat nilai $\geq 75$

$\mathrm{N}=$ jumlah siswa

\section{HASIL DAN PEMBAHASAN}

Berdasarkan hasil penelitian yang telah dilaksankan dengan menerapkan model pembelajaran PBL untuk meningkatkan aktivitas dan hasil belajar IPA siswa kelas $\mathrm{VII}_{1}$ SMPN 14 kota bengkulu materi ekosistem yang dilaksanakan selama dua siklus diperoleh hasil sebagai berikut:

Observasi aktivitas guru digunakan sebagai acuan observer untuk mengetahui kelebihan dan kekurangan yang dilakukan guru pada saat proses pembelajaran berlangsung dan sebagai pedoman untuk memperbaiki pelaksanaan proses belajar mengajar pada siklus selanjutnya. Adapun Analisis hasil observasi aktivitas guru dari masingmasing siklus dapat dilihat pada Tabel 4.1 berikut.

Tabel 4.1 Analisis Data Hasil Observasi Aktivitas Guru pada Tiap Siklus

\begin{tabular}{lcc}
\hline \multicolumn{1}{c}{ Penilai } & Siklus I & Siklus II \\
\hline Observer & 30,6 & 31,6 \\
Kriteria & Baik & Baik \\
\hline
\end{tabular}

Observasi aktivitas siswa digunakan sebagai acuan observer untuk mengetahui sejauh mana keaktifan dan keikutsertaan siswa dalam mengikuti proses belajar pada setiap tahap-tahap pembelajaran. Adapun analisis data hasil observasi aktivitas siswa secara dari masingmasing siklus dapat dilihat pada Tabel 4.2 berikut.

Tabel 4.2 Analisis Data Hasil Observasi Aktivitas Siswa pada Siklus I

\begin{tabular}{lcc}
\hline Penilai & Siklus I & Siklus II \\
\hline Observer & 30,6 & 31 \\
Kriteria & Baik & Baik \\
\hline
\end{tabular}

Adapun presentase ketuntasan klasikal siswa pada tiap siklus dapat dilihat pada Tabel 4.3 berikut.

Tabel 4.3 Presentase Ketuntasan Klasikal Siswa Tiap Siklus

\begin{tabular}{lcc}
\hline \multicolumn{1}{c}{ Penelitian } & \multicolumn{1}{c}{ Siklus } & \multicolumn{1}{c}{$\begin{array}{c}\text { Siklus } \\
\text { II }\end{array}$} \\
\hline $\begin{array}{l}\text { Jumlah siswa yang } \\
\text { memperoleh nilai } \\
\geq 75\end{array}$ & 24 orang & 30 orang \\
$\begin{array}{l}\text { Presentase } \\
\text { ketuntasan belajar } \\
\text { klasikal }\end{array}$ & $70,6 \%$ & $88,2 \%$ \\
Kriteria & $\begin{array}{l}\text { Tidak } \\
\text { tuntas }\end{array}$ & Tuntas \\
\hline
\end{tabular}

Berdasarkan analisis dan hasil yang didapat dalam penelitian yang telah dilakukan dengan menerapkan model PBL pada pokok bahasan Ekosistem pada siklus I, dan II dapat meningkatkan 
aktivitas guru dan aktivitas siswa selama proses pembelajaran berlangsung dikelas $\mathrm{VII}_{1}$ SMPN 14 Kota Bengkulu. Peningkatan aktivitas guru dan aktivitas siswa dari siklus I hingga siklus II dapat di lihat pada Grafik 4.1 sebagai berikut.

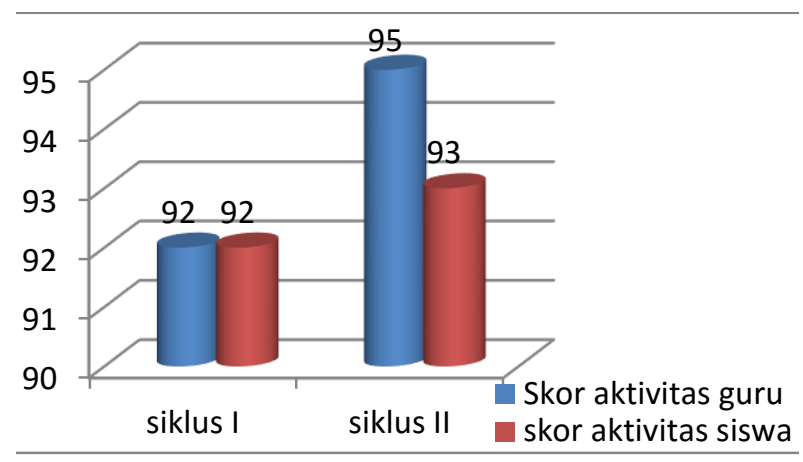

Grafik 4.1 Peningkatan Aktivitas guru dan Aktivitas Siswa pada Siklus I dan II

Berdasarkan Grafik 4.1 diatas, dapat dideskripsikan bahwa penelitian dengan menerapkan model PBL telah meningkatkan aktivitas guru dan aktivitas siswa. Dimana pada siklus I skor yang diberikan observer untuk aktivitas guru adalah 92 yang menyatakan bahwa proses pembelajaran yang dilakukan guru sudah berjalan baik, kemudian pada siklus II terjadi peningkatan skor menjadi 95 yang dinyatakan kedalam kriteria baik. Hal ini juga didukung dengan aktivitas belajar siswa yang diamati oleh observer, dimana pada siklus I aktivitas siswa menunjukan kategori baik dengan skor 92, dan meningkat pada siklus II menjadi 93. Pada proses pembelajaran dengan menerapkan model PBL di dalam penelitian ini menggunakan 2 siklus pada pokok bahasan Ekosistem. Dimana siklus I diterapkan pada submateri komponen penyusun ekosistem, selanjutnya siklus II diterapkan pada sub materi satuansatuan mahluk hidup.

Hal tersebut dipengaruhi oleh aktivitas guru dan siswa di dalam proses pembelajaran, dimana pada siklus I masih terdapat aspek-aspek berkriteria cukup.
Hal ini berpengaruh terhadap hasil belajar siswa itu sendiri. Walaupun pembelajaran dengan menerapkan model PBL pada siklus I ini telah berjalan dengan baik. Sehingga disiklus II pada aspek-aspek yang berkriteria cukup tersebut dilakukan perbaikan-perbaikan dalam proses pembelajaran agar siswa memperoleh hasil belajar yang lebih optimal. Hal ini karena di pengaruhi oleh keaktifan siswa selama mengikuti proses pembelajaran yang akan berdampak pada hasil belajar siswa, peningkatan keaktifan siswa tersebut terlihat dari aktivitas siswa selama proses pembelajaran. Menurut Rusman (2014) aktivitas belajar siswa meliputi aktivitas fisik maupun mental dan menghasilkan perubahan nilai atau sikap positif pada dirinya dengan bimbingan dan tanggung jawab guru sebagai pembimbing dan sumber belajar yang baik serta dilakukan melalui proses yang direncanakan dan dilaksanakan sebagai suatu sistem untuk mencapai hasil belajar yang optimal. Berdasarkan hasil penelitian ini, maka dapat di tarik kesimpulan bahwa penerapan model PBL dapat meningkatkan aktivitas guru dan siswa dalam proses pembelajaran.

Tahapan kegiatan pembelajaran dengan menerapkan model pembelajaran problem based learning dikelas VII 1 SMPN 14 Kota Bengkulu yang dilakukan selama dua siklus ini masingmasing sesuai dengan tahapan-tahapan yang dikemukakan oleh Ibrahim dan Nur (2000) dalam Rusman (2014) yaitu terdiri dari tahapan 1) orientasi siswa pada masalah, 2) Mengorganisasi siswa untuk belajar, 3) Membimbing pengalaman individu/kelompok, 4) Mengembangkan dan menyajikan hasil karya, dan 5) Menganalisis dan mengevaluasi proses pemecahan masalah.

Pada siklus I dan siklus 2 ditahap mengorientasikan siswa pada masalah, guru menampilkan gambar. 
Ditampilkannya situasi kepada masalah dengan fenomena dari pengalaman yang sering ditemukan oleh siswa dalam kehidupan sehari-hari yaitu dengan tujuan menarik minat siswa untuk belajar berdasarkan penjelasan dari Permendikbud (2014) yang menyatakan bahwa Pembelajaran Berbasis Masalah (Problem Based Learning) merupakan sebuah model pembelajaran yang menyajikan berbagai permasalahan nyata dalam kehidupan sehari-hari siswa (bersifat kontekstual) sehingga merangsang siswa untuk belajar.

Pada siklus I dan siklus II guru mengorganisasikan siswa kedalam kelompok-kelompok belajar, dimana pada siklus I guru telah membentuk siswa ke dalam 6 kelompok-kelompok belajar secara heterogen, dalam satu kelompok masing-masing terdiri dari siswa perempuan dan siswa laki-laki yang beranggota $5-6$ orang siswa. Selain itu, adapun kegiatan guru selama proses pembelajaran pada tahap ini yaitu membagikan LKS. Dengan terlaksananya kegiatan tersebut, membantu berlangsungnya pembelajaran dengan baik.

Pada siklus I dan II adapun kegiatan yang dilakukan guru dalam membimbing individu/kelompok yaitu membimbing siswa mengumpulkan data, dan diskusi kelompok siswa dalam menjawab pertanyaan di LKS. Pada proses pembelajaran ini guru sangat menekankan kegiatan siswa baik dalam kegiatan pengamatan maupun diskusi kelompok untuk memecahkan suatu masalah, hal ini sesuai dengan tujuan utama dari pembelajaran PBL menurut Hosnan (2014) yaitu untuk mengembangkan kemandirian belajar dan keterampilan sosial peserta didik, kemandirian belajar dan keterampilan sosial itu dapat terbentuk ketika peserta didik berkalaborasi untuk mengidentifikasi informasi, strategi, dan sumber belajar yang relevan untuk menyelesaikan masalah.

Pada siklus I dan II pada tahap ini, adapun kegiatan yang dilakukan guru yaitu memberi kesempatan kepada setiap perwakilan kelompok untuk melakukan presentasi didepan kelas. Namun berdasarkan penilaian ketiga observer pada kegiatan diskusi kelompok, guru kurang melakukan penegasan jawaban terhadap pertanyaan maupun tanggapan yang diajukan oleh kelompok peserta kepada kelompok penyaji. Hal ini dikarenakan kurang tepatnya waktu presentasi sehingga tidak sesuai dengan waktu yang telah ditentukan oleh guru sebelumnya.

Pada siklus I dan II adapun kegiatan yang dilakukan guru ditahap menganalisis dan mengevaluasikan proses pemecahan masalah yaitu guru membimbing siswa untuk menarik kesimpulan dari hasil pembelajaran yang telah dilakukan, kesimpulan pembelajaran tersebut merupakan jawaban dari tujuan pembelajaran yang dilakukan.

Pada siklus I dan II siswa terlihat termotivasi saat guru menyajikan situasi pada masalah, pada pembelajaran siklus I semua siswa terlihat antusias mengamati gambar, dan memberikan pertanyaanpertanyaan mengenai terkait gambar tersebut. Adapun tujuan diberikannya pertanyaan-pertanyaan tersebut menurut Sanjaya (2008) dalam Rusman (2014) yaitu untuk memberikan bantuan dan membimbing sehingga mendorong siswa untuk belajar. Antusiasnya siswa terhadap permasalahan yang disajikan guru pada tahap ini membantu berlangsungnya pembelajaran dengan baik.

Pada siklus I dan II siswa membentuk kelompok-kelompok belajar sesuai dengan arahan guru, Selain itu, adapun kegiatan siswa dalam proses 
pembelajaran pada tahap ini yaitu mendengarkan guru menjelaskan langkah kerja LKS.

Adapun kegiatan pengamatan yang dilakukan di siklus I yaitu mengumpulkan data terhadap komponen-komponen yang terdapat dalam suatu ekosistem yaitu komponen biotik dan abiotik di halaman sekolah SMPN 14 Kota Bengkulu. Sedangkan pada siklus II adapun kegiatan pengamatan yang dilakukan siswa yaitu menghitung kepadatan populasi tumbuhan putri malu (Mimosa pudica) di halaman sekolah SMPN 14 Kota Bengkulu khususnya terletak dihalaman belakang kelas $\mathrm{VII}_{1}$ dengan luas lokasi pengamatan $\pm 50 \mathrm{~m}$.

Pada siklus I dan II adapun kegiatan yang dilakukan siswa di tahap ini yaitu setiap kelompok siswa melakukan presentasi didepan kelas, yaitu menyampaikan hasil pengamatan dan hasil diskusi dari pertanyaan yang ada di LKS, pada tahap ini kegiatan presentasi dilakukan oleh satu orang siswa sebagai perwakilan dari setiap kelompok.

Pada siklus I dan II adapun kegiatan yang dilakukan siswa di tahap ini yaitu menyampaikan kesimpulan pembelajaran sesuai dengan pertanyaan yang diberikan oleh guru, dan mengerjakan soal post tes. Pada tahap ini sebagian siswa bisa menjawab dengan baik dan ada juga siswa menjawab dengan jawaban yang kurang tepat hal ini dikarenakan masih ada anggota kelompok siswa yang kurang serius melakukan pengamatan ataupun diskusi kelompok, terlihat ketika kegiatan pembelajaran ada sebagian siswa dalam kelompok tersebut sering melakukan aktivitas di luar kegiatan belajar seperti mengobrol, mengganggu temannya yang lain sehingga menyebabkan siswa tersebut mrnjadi kurang paham terhadap konsep yang dipelajari selama proses pembelajaran dilakukan.
Berdasarkan hasil analisis soal post tes siswa, terlihat masih ada siswa yang belum tuntas secara individu dan klasikal. Maka pada siklus I menunjukan bahwa dari 10 soal post tes yang telah dibuat oleh guru pada soal no 10 merupakan soal yang paling sulit untuk dijawab oleh siswa. Pada soal no 10 dengan tingkat kognitif $\mathrm{C} 2$ siswa banyak menjawab salah, sedangkan soal yang paling banyak di jawab benar oleh siswa pada siklus I ini yaitu soal no 2 dengan tingkat kognitif $\mathrm{C} 1$. Sehingga pada siklus I ini, ketuntasan belajar klasikal siswa belum sepenuhnya tercapai dengan baik namun secara individu sudah sebagian besar siswa tuntas akan hasil belajar mereka. Namun sebagian besar juga hasil belajar siswa masih belum tuntas, hal ini dikarena siswa belum terbiasa dengan model pembelajaran yang diterapkan oleh guru selama ini yaitu dengan pembelajaran PBL dan jarang sekali siswa dibentuk dalam kelompok. Hal ini terlihat ketika mereka telah berada dalam kelompok kooperatif masingmasing, mereka belum bisa bekerjasama dan berdiskusi dengan baik dalam menyelesaikan permasalahanpermasalahan yang diberikan oleh guru sehingga hanya ada beberapa orang saja yang terlihat aktif di dalam anggota kelompok tersebut.

Pada siklus II analisis soal post tes menunjukan bahwa soal yang sulit dijawab oleh siswa adalah soal no 6 . Soal no 6 merupakan soal yang mempunyai tingkat kognitif C2 (pemahaman). Sedangkan untuk soal yang paling banyak di jawab benar oleh siswa adalah soal no 7 dan no 10 dimana pada soal no 7 siswa diminta untuk menyebutkan salah satu satuan mahluk hidup dengan petunjuk sebuah gambar sekumpulan empat populasi hewan dengan tingkat kognitif C2 (pemahaman). Sedangkan soal no 10 siswa diminta untuk menyebutkan nama lain dari tempat hidup suatu organisme 
yang sudah di pelajari sebelumnya pada pemecahan masalah di LKS. Soal no 7 dan 10 dapat dijawab dengan baik oleh siswa karena pada saat pengamatan dan diskusi mengenai satuan-satuan mahluk hidup, siswa berpartisipasi secara aktif menyelesaikan masalah yang terdapat dalam LKS selama proses pembelajaran berlangsung yang menandakan bahwa siswa sudah mulai terbiasa dengan model pembelajaran PBL yang sudah diterapkan oleh guru pada pembelajaran sebelumnya yaitu di siklus I pada sub materi komponen penyusun ekosistem. Hal ini terlihat ketika mereka telah berada dalam kelompok kooperatif masing-masing, mereka sudah bisa bekerjasama dan berdiskusi dengan baik dalam menyelesaikan permasalahanpermasalahan yang diberikan oleh guru.

Meningkatnya hasil belajar siswa pada siklus II merupakan hasil dari perbaikan dari siklus I dimana setelah melakukan evaluasi terhadap kelemahan-kelemahan hasil belajar siswa, sehingga dilakukanlah perbaikanperbaikan di pembelajaran siklus II. Sesuai dengan pendapat Arifin (2012) bahwa hasil evaluasi dapat dimanfaatkan untuk membangkitkan minat dan motivasi belajar. Hal ini dapat dilakukan jika peserta didik mengetahui hasil evaluasi yang dicapainya, mengetahui kesalahan-kesalahannya dan bagaimana solusinya. bagi guru, hasil evaluasi dapat dimanfaatkan untuk mendiagnosis peserta didik yang memiliki kelemahan atau kekurangan, baik secara perseorangan maupun kelompok. Berdasarkan kelemahan-kelemahan ini, maka guru harus mencari faktor-faktor penyebabnya, antara lain dari sistem evaluasi itu sendiri, materi pelajaran, kemampuan guru, kemampuan peserta didik, perencanaan dan pelaksanaan pembelajaran, serta lingkungan
Hasil penelitian yang telah dilaksanakan selama dua siklus pada pembelajaran IPA di kelas $\mathrm{VII}_{1}$ SMPN 14 Kota Bengkulu dengan menerapkan model PBL ini dapat diketahui telah terjadi peningkatan hasil belajar IPA siswa, peningkatan ini dapat dilihat pada Grafik 4.2 persentase peningkatan hasil belajar siswa berikut.

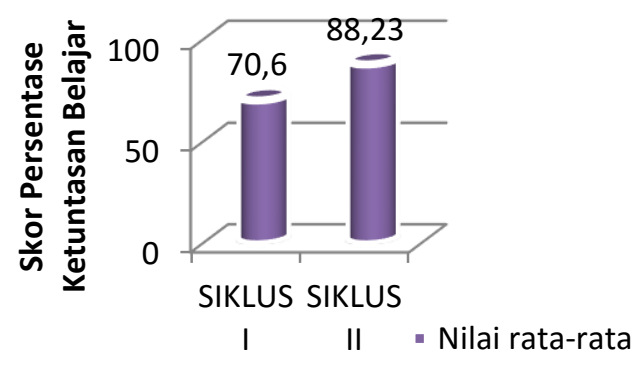

Grafik 4.2 Ketuntasan Belajar Siswa Secara Klasikal pada Pembelajaran Siklus I dan II Berdasarkan Grafik 4.2 diatas, terlihat dimana presentase ketuntasan belajar klasikal pada siklus II ini adalah $88,2 \%$ sudah termasuk kriteria tuntas secara klasikal untuk kompetensi pemahaman konsep karena dari 34 orang siswa yang memperoleh nilai $\geq 75$ sebanyak 30 orang siswa yang tuntas dan sisanya 4 orang yang belum tuntas. Berdasarkan hasil pengamatan terhadap aktivitas guru dan siswa pada siklus II pembelajaran dengan menerapkan model PBL pada siklus II ini telah berjalan dengan baik. Hal ini dapat dilihat pada hasil belajar siswa yang mengalami peningkatan dari siklus I ke siklus II dengan presentase siklus I yang sebelumnya $70,6 \%$ terjadi peningkatan $17,6 \%$ menjadi $88,2 \%$ pada siklus II. Secara terperinci nilai hasil belajar siswa dapat di lihat pada (Lampiran 33 dan 34).

Peningkatan hasil belajar ini diperoleh dari hasil tindak belajar siswa dan tindak mengajar guru terhadap siswa hal ini sesuai dengan pendapat Arifin (2012) bahwa hasil belajar merupakan dampak tindakan guru, suatu pencapaian tujuan pembelajaran. Pada bagian lain, hasil belajar merupakan peningkatan 
kemampuan mental peserta didk melalui berbagai jenis perbuatan atau pembentukan tingkah laku peserta didik itu sendiri diantaranya dari kebiasaan, keterampilan, akumulasi persepsi, asosiasi dan hafalan, pemahaman, sikap, nilai, serta moral.

\section{PENUTUP}

\section{Simpulan}

Berdasarkan hasil penelitian dengan menerapkan model Problem Based Learning (PBL) di kelas $\mathrm{VII}_{1}$ SMPN 14 Kota Bengkulu dalam pembelajaran IPA pada materi Ekosistem dapat disimpulkan bahwa terdapat peningkatkan aktivitas mengajar guru. Hal ini dibuktikan dari hasil observasi yang dilakukan oleh tiga orang observer pada siklus I untuk aktivitas guru diperoleh rerata 30,6 dan meningkat di siklus II menjadi 31,6 yang dinyatakan dengan kriteria baik. Sedangkan untuk aktivitas siswa pada siklus I diperoleh rerata 30,6 serta meningkat di siklus II menjadi 31 yang dinyatakan dengan kriteria baik dan dapat meningkatkan hasil belajar siswa di kelas $\mathrm{VII}_{1}$ SMPN 14 Kota Bengkulu, hal ini dibuktikan dari hasil tes siswa pada siklus I diperoleh persentase hasil belajar (KBM) yaitu $70,6 \%$ meningkat pada siklus II menjadi $88,2 \%$.

\section{Saran}

Untuk peneliti selanjutnya sebaiknya guru dapat menerapkan model Problem Based Learning (PBL) sebagai model alternatif pembelajaran IPA baik pada kurikulum KTSP/ 2013 pada materi ekosistem khususnya pada sub materi komponen penyusun ekosistem dan satuan-satuan mahluk hidup untuk meningkatkan aktivitas guru dan siswa dalam pembelajaran serta hasil belajar siswa dan guru dapat menerapkan model Problem Based Learning (PBL) dengan penyajian masalah yang lebih menarik lagi, seperti menggunakan media, atau menggunakan video terkait materi ekosistem.

\section{DAFTAR PUSTAKA}

Arifin, Zainal. 2012. Evaluasi Pembelajaran. Bandung: PT Remaja Rosdakarya

Darmadi, H. 2014. Metode Penelitian Pendidikan dan Sosial. Bandung: Alfabeta.

Hosnan, M. 2014. Pendekatan Saintifik dan Kontekstual dalam Pembelajaran Abad 21. Bogor: Ghalia Indonesia.

Peraturan Menteri Pendidikan dan Kebudayaan Republik Indonesia Nomor 58 Tahun 2014 tentang Kurikulum 2013 Sekolah Menengah Pertama/Madrasah Tsanawiyah.

Rusman. 2014. Model-Model Pembelajaran. Jakarta: Rajawali Pers.

Trianto. 2011. Panduan Lengkap Penelitian Tindakan Kelas (Classroom Action Research): Teori dan Praktik. Jakarta: Prestasi Pustaka Publisher 